\title{
Human-mediated long-distance jumps of the pine processionary moth in Europe
}

\author{
Christelle Robinet • Charles-Edouard Imbert • \\ Jérôme Rousselet • Daniel Sauvard · Jacques Garcia • \\ Francis Goussard · Alain Roques
}

Received: 23 April 2010/Accepted: 2 March 2011/Published online: 18 March 2011

(C) The Author(s) 2011. This article is published with open access at Springerlink.com

\begin{abstract}
Although climate change is currently affecting the distribution of many species, insects are particularly impacted because of their high sensitivity to temperature. The pine processionary moth, Thaumetopoea pityocampa, is a forest insect extending its distribution in response to climate warming. Some pioneer colonies were recently detected far beyond the main range, near Paris and in eastern France. This study tracked the origin and pathways of these pioneer colonies through a combined use of genetic markers, measurement of female flight capabilities, and comparative analyses of the natural enemy complexes. This study also aimed to determine the establishment capability beyond the main range, considering the survival rate during two recent cold periods. The larval survival rate was higher in pioneer colonies (which behave like urban heat islands) than in main range. The flight capacity of females would not have allowed them to come from the main range or the nearest established colonies, and molecular tools further showed that
\end{abstract}

Electronic supplementary material The online version of this article (doi:10.1007/s10530-011-9979-9) contains supplementary material, which is available to authorized users.

C. Robinet · C.-E. Imbert · J. Rousselet .

D. Sauvard · J. Garcia · F. Goussard · A. Roques ( $\square$ )

INRA UR633 Zoologie Forestière, 2163 avenue de la pomme de pin, CS 40001 Ardon, 45075 Orléans cedex 2, France

e-mail: alain.roques@orleans.inra.fr individuals from at least three pioneer colonies were not assigned or similar to individuals at the edge of the main range. Egg parasitoids were absent while pupal parasitoids were present in the pioneer colonies suggesting an introduction at the pupal stage. These approaches provided strong evidence that this species has been accidentally moved near Paris and to eastern France, supporting the hypothesis of human-mediated transportation over natural dispersal. This type of dispersal was unexpected because of risks from urticating hairs and the easy detection of the species.

Keywords Climate change - Flight capacity · Genetic assignment tests - Human mediated dispersal · Invasion · Natural enemies . Urticating caterpillar

\section{Introduction}

Climate change has been shown to induce significant responses from insect species (Parmesan and Yohe 2003; Battisti et al. 2005; Parmesan 2006; Netherer and Schopf 2010; Robinet and Roques 2010). Although this change involves simultaneous and complex, non-linear variations in many environmental variables, the increase in air temperature has been the most studied and is likely to play a key role (Trenberth et al. 2007). Insects are essentially ectothermic organisms with their physiological processes highly sensitive to ambient temperatures (Beck 
1983). Their development, population dynamics and geographic distribution are therefore likely to respond quickly to temperature increases (see Robinet and Roques 2010 for a review). Temperature thresholds often delimit one or more boundaries of a species' geographic range (Andrewartha and Birch 1984). Such climate change may remove/relocate boundaries that limit spread and so allow some range expansion into areas where the species had been previously kept in check by climatic factors (Walther et al. 2002). For example, as average climatic isotherms have moved northwards by $120 \mathrm{~km}$ during the past century, 63\% of non-migratory European butterflies have extended their ranges by 35-240 km northwards (Parmesan et al. 1999).

Populations of alien organisms are considered more likely to establish if they are introduced into areas with similar climatic conditions to their native distribution. Similarly alien species introduced into new areas colder than their native range manage to survive only because of 'islands' of habitat heated by human activity, such as urban areas or other anthropogenic habitats. Global warming could provide new opportunities for successful introduction of alien species into areas where, until recently, such species would not have been able to survive (Walther et al. 2009).

Following the establishment of alien organisms in an area, spread is often not continuous but proceeds with jump dispersal ahead of the population forming isolated new populations that ultimately coalesce (Shigesada and Kawasaki 1997). Liebhold and Tobin (2008) pointed out the importance of long-distance dispersal events on the spread of many invading insects such as the horse-chestnut leaf miner, Cameraria ohridella (Deschka and Dimić) (Lepidoptera: Gracillaridae) in Europe (Gilbert et al. 2004), the emerald ash borer, Agrilus planipennis (Fairmaire) (Coleoptera: Buprestidae), in the Eastern North America (Muirhead et al. 2006), and the European gypsy moth, Lymantria dispar (Linnaeus) (Lepidoptera: Lymantriidae) in the US (Sharov and Liebhold 1998). Such events similarly affect the pine wood nematode, Bursaphelenchus xylophilus (Steiner and Buhrer) Nickle (Nematoda: Aphelenchoididae), in China (Robinet et al. 2009). Even if long-distance dispersal is not so frequent, it can substantially increase the invasion speed (Neubert and Caswell 2000) and the maximum annual spread distance could be the most critical parameter to predict this (Koch et al. 2009). In pest surveillance and containment strategies, it is also important to determine whether long-distance dispersal could be attributed to human transportation. However, in native species it is often more difficult to distinguish natural migration processes and human-mediated colony movements (Walther et al. 2009).

The pine processionary moth (PPM), Thaumetopoea pityocampa Denis and Schiffermüller (Lepidoptera: Notodontidae) is one of the most important defoliating pests of pine stands in Europe. Originally from the Mediterranean, this moth is naturally expanding its range in recent times towards higher latitudes and altitudes (Battisti et al. 2005). Developing gregariously during winter within conspicuous white silk nests, the moth is highly sensitive to small variations in temperature. The range expansion is associated with better winter survival and enhanced feeding activity caused by rising mean ambient temperatures (Battisti et al. 2005; Buffo et al. 2007). Temperature-dependent models of PPM feeding activity suggested an unfavorable area in the South of the Paris Basin (France), which may have constrained the distribution of this insect under pre1990s climatic conditions. Since 2000 increasing temperatures have allowed this moth to cross this area and it is expanding its range north by ca. $5.6 \mathrm{~km}$ per year (Robinet et al. 2007). This insect was considered to be easy to detect because of its obvious winter nests and its highly urticating larvae (Battisti et al. 2011), and therefore unlikely to have moved, even indirectly, by humans. Nonetheless pioneer colonies were recently discovered in the vicinity of Paris and in eastern France far beyond the limits of the main range of the species (Robinet et al. 2010). It was unclear whether these pioneer colonies were translocated by human activities or resulted from natural expansion of the species.

Our objective was to investigate the mechanism of this population expansion, exploring the dispersal mechanism and the species establishment capability. More precisely we (i) determined the origin and pathways of colonization through a combination of genetic markers, measurement of female flight capabilities, and comparative analyses of natural enemies, and (ii) then compared the temperature suitability of the colonized locations with the main range, based on data collected during recent cold periods. 


\section{Materials and methods}

\section{Description of pioneer colonies}

Hereafter the term colony refers to a set of PPM nests located in a given area rather than the nest itself where the larvae develop gregariously. The discovery of such isolated colonies was reported by phytosanitary managers and the public, because national surveys to detect small and isolated pioneer colonies are too costly (in terms of individuals and time) (Table 1). Such reports were then confirmed by INRA scientists. Prior to 2008 , six pioneer colonies were found; five in the vicinity of Paris (see Appendix S1) and one in Eastern France (Obernai) (Fig. 1; Table 1). These colonies were mainly located in urban areas, where the human population density is relatively high compared to the average density in France (about 100 inhabitants per $\mathrm{km}^{2}$ ) (Table 1). A large media effort to inform the public of the health hazard of PPM (because of the larval urticating hairs), and a subsequent national PPM survey (Leblond et al. 2010) means it unlikely that any other pioneer population escaped detection, especially colonies that might have acted as a bridge between the main range and already detected pioneer colonies.

Dispersal mechanism

\section{Dispersal capabilities}

PPM natural dispersal is directly dependent on the flight capacity of the females. To determine whether a female can fly from the known range to the pioneer colonies, we (1) estimated their flight capacity and (2) calculated the distance a female needed to fly to reach these pioneer colonies.

(1) Previously the female flight capacity has been estimated as varying from between a few hundred metres to more than two kilometres without any nearby suitable host trees (Démolin 1969; Devkota et al. 1992). However, the observed rate of PPM expansion in the Paris Basin (5.6 km per year between 1972 and 2004; Battisti et al. 2005) greatly exceeds these estimates. In reality the female flight capacity is poorly understood due to the difficulty of measuring it in the field. A flight mill adapted to the size and weight of the PPM adult female was therefore used to estimate its flight capacity under laboratory conditions. In March 2009, just before larval pupation, 40 nests were collected from the northern edge of the main range in the Paris Basin (west to Chartres within ten metres of $48^{\circ} 27^{\prime} 26^{\prime \prime} \mathrm{N} ; 1^{\circ} 27^{\prime} 6^{\prime \prime} \mathrm{E}$ ). The nests were maintained in outdoor conditions at the INRA laboratory (Orléans), where insects pupated. The emerging females were tested using flight mill in July 2009, and the cumulated flight distance over $24 \mathrm{~h}$ was measured for each female.

(2) To determine whether the females could reach the pioneer colonies by themselves, we calculated the distance from the colony to (a) the main range and (b) the nearest other pioneer

Table 1 Description of pioneer colonies beyond the PPM main range

\begin{tabular}{lllll}
\hline Location & Coordinates & First detection & Source & Human density \\
\hline Bailly-Romainvilliers & $48.85 \mathrm{~N} ; 02.80 \mathrm{E}$ & 2003 & INRA $^{\mathrm{a}}$ & 811 \\
Nanterre & $48.91 \mathrm{~N} ; 02.22 \mathrm{E}$ & 2007 & INRA $^{\mathrm{a}}$ & 6,572 \\
Aubergenville & $48.97 \mathrm{~N} ; 01.85 \mathrm{E}$ & 2008 & FREDON $^{\mathrm{b}}$ & 655 \\
Eragny & $49.02 \mathrm{~N} ; 02.10 \mathrm{E}$ & 2008 & Private individual $^{2}$ & 2,554 \\
Saint-Maur-Des-Fossés & $48.79 \mathrm{~N} ; 02.50 \mathrm{E}$ & 2008 & Private individual $^{\text {ind }}$ & 2,659 \\
Obernai & $48.46 \mathrm{~N} ; 07.50 \mathrm{E}$ & 2008 & DSF $^{\mathrm{c}}$ & 329 \\
\hline
\end{tabular}

Grid references are means of infested trees at the first year of detection in decimal degrees. Establishment of these colonies may have taken place some years before their discovery. Human population density in 2005 at the given locations is expressed as the number of inhabitants per $\mathrm{km}^{2}$ (source: Gridded Population of the World, http://sedac.ciesin.columbia.edu/gpw)

a INRA: French National Institute for Agricultural Research

b FREDON: French Regional Federation for the Defence against Pest Organisms

c DSF: Forest Health Department of the French Ministry of Food, Agriculture and Fisheries 
Fig. 1 a Experimental design: pioneer colonies detected up until 2008 and sampling sites for genetic analyses and investigation of natural enemies. The main range of PPM in mainland France is also represented (2005-2006 data, modified from Robinet et al. 2010). b Focus on locations near Paris and closeness of the PPM main range (delimited by the rectangle in figure (a)), with sample sites for the genetic analyses, investigation of natural enemies, and establishment capability. Where multiple symbols relate to a site these are contained in a white rectangle

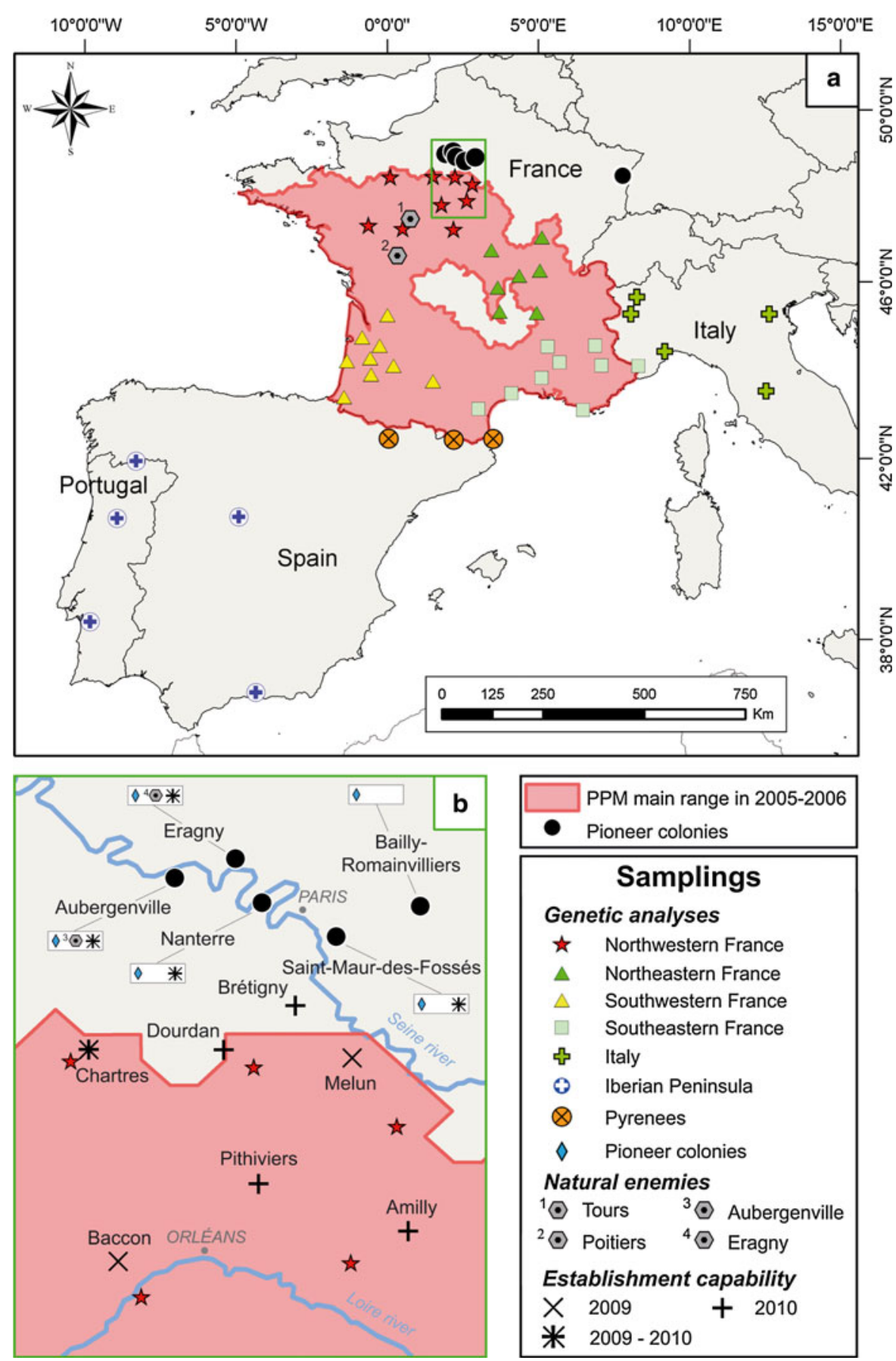

colony. More precisely we calculated the distance between the edge of the main range recorded during the winter 2005-2006 (the most recent national estimate; Robinet et al. 2010) and the mean geographical coordinates of the infested trees in the first year of colony detection. We then calculated the minimum distance between the mean geographical coordinates of the pioneer colony in the first year of detection and the coordinates of trees infested the years before in other pioneer colonies. For this purpose GIS software (ArcInfo 9.2; ESRI) 
was used to transform the geographic coordinate system into the projected coordinate system 'Lambert 2 étendu' (French national grid system in metric units) and the distance calculated.

\section{Genetic analyses}

Genetic markers were used to assess whether the five pioneer colonies occurring near Paris originated from the nearest populations in the main range (i.e. the expansion area into north-western France), or came from further away. A total of 51 individuals from the pioneer colonies were genotyped for five nuclear microsatellite markers (for protocols see Rousselet et al. 2004). Three to 15 individuals were analyzed per population but only one individual per sampled tree. Furthermore, 20 individuals (four per population sample and one per tree) were sequenced for a fragment of the mitochondrial Cytochrome c oxidase subunit I (COI) gene (see Rousselet et al. 2010). In order to assign these individuals to a likely source population, a total of 705 individuals were genotyped from seven areas in Western Europe for the same microsatellite loci. These seven groups were defined on the basis of the population genetic structure revealed in previous genetic studies (Salvato et al. 2002; Salvato et al. 2005; Kerdelhué et al. 2006; Santos et al. 2007; Kerdelhué et al. 2009; Rousselet et al. 2010). These groups were located in northwestern France (135 individuals from nine populations), south-western France (135 individuals from nine populations), the Pyrenees (45 individuals from three populations), south-eastern France (135 individuals from nine populations), north-eastern France (105 individuals from seven populations), Italy (75 individuals from five populations), and the Iberian Peninsula (75 individuals from five populations) (Fig. 1). The Balkans and North Africa were not sampled. The coordinates of all sampling locations are given in the electronic supplementary material (Appendix S2).

In order to attribute each individual from the pioneer colonies to one of the four strongly geographically-structured maternal lineages described in Europe, mitochondrial DNA sequences were aligned using Bioedit 7.05 (Hall 1999) with the mitotype sequences previously published and deposited in Genbank (accession numbers GU385906-GU385951;
Rousselet et al. 2010). Each lineage can be characterized by the nucleotide occurring at the positions 634, 654, 724, 735, 736, 744 (see appendix S2 in Rousselet et al., 2010). Mitogroup $A_{1}$ is characterized by the combination $\mathrm{T}-\mathrm{T}-\mathrm{C}-\mathrm{C}-\mathrm{C}-\mathrm{C}$ at these positions and is found in eastern France, Italy and Balkans. Mitogroup $\mathrm{A}_{2}$ is characterized by $\mathrm{T}-\mathrm{T}-\mathrm{C}-\mathrm{C}-\mathrm{T}-\mathrm{C}$ and is found in western France and in eastern Spain. Mitogroup $\mathrm{A}_{3}$ is characterized by $\mathrm{C}-\mathrm{C}-\mathrm{C}-\mathrm{C}-\mathrm{T}-\mathrm{C}$ and occurs in the Pyrenees. Mitogroup B is characterized by $\mathrm{T}-\mathrm{T}-\mathrm{T}-\mathrm{T}-\mathrm{T}-\mathrm{T}$ and occurs in central and western Spain and in Portugal.

For microsatellite multilocus data, a Bayesian assignment test was carried out as implemented in Geneclass 2 software (Piry et al. 2004) to assign individuals to reference populations using the method of Rannala and Mountain (1997). Probability computations were calculated with 10,000 simulated individuals used in Monte Carlo re-sampling as recommended by Paetkau et al. (2004).

\section{Natural enemies}

The co-occurrence or disjunction between a species and its specialist natural enemies can provide additional information about the origin of pioneer colonies and, in some cases, can be helpful to discriminate between colonization pathways. Therefore, the presence/absence of natural enemies was assessed in two pioneer colonies near Paris (Eragny and Aubergenville) and compared to natural enemy populations from two colonies in the main range (Poitiers and Tours) (Fig. 1). This study focused on both egg and larval parasitoids because egg and larval parasitoids can strongly affect PPM populations. The egg parasitism rate can vary from 2 to $45 \%$ within a batch (Pimentel et al. 2010), with up to $100 \%$ of eggmasses being parasitized in a colony (Biliotti 1958), while the larval parasitism rate can reach $30 \%$ (Biliotti 1956). Egg-masses and winter nests were also relatively easy to collect compared to the shortlived adults and pupae buried in the soil.

(1) Sixteen to twenty-five egg-masses were sampled in the four locations in September 2008 after the larvae hatched. Egg-masses were put singly in test tubes with a cotton stopper to collect emerging parasitoids. After parasitoid 
emergence, the scales of the egg-masses were removed and the number of hatched larvae and emerged parasitoids was recorded (Tanzen and Schmidt 1995).

(2) Ten to twenty PPM nests were sampled at the same four locations during winter 2009-2010 (except for Poitiers where ten nests were collected during winter 2008-2009) to compare the presence/absence of the specific larval-pupal parasitoid Phryxe caudata (Rondani, 1859) (Diptera: Tachinidae) between pioneer colonies and those located in the main range.

Establishment capability

PPM is sensitive to the severity and duration of the cold period, because it completes larval development in winter. The lethal temperature threshold is between approximately -10 and $-16^{\circ} \mathrm{C}$ (Huchon and Démolin 1970; Battisti et al. 2005). Temperature thresholds associated with the larval feeding activity also contribute significantly to survival in the expansion area (Battisti et al. 2005; Robinet et al. 2007). Since the survival rate of populations decreases along the expansion gradient (Battisti et al. 2005), we explored the climatic suitability in the pioneer colony locations. More precisely, survival rates and temperatures during cold periods (which occurred in France in January 2009 and January 2010) were compared in the pioneer colonies and in the main range.

Two to five days after these cold periods (in late January), we collected some nests from the pioneer colonies (excluding Bailly-Romainvilliers because of low population density and Obernai because of access) and in the main range to compare the survival rates. In 2009, nests were collected at Eragny $(n=5)$, Aubergenville $(n=5)$, Nanterre $(n=5)$, Saint-Maur-desFossés $(n=5)$, but also in the main range, at Baccon $(n=10)$, Chartres $(n=10)$, Melun $(n=10)$. In 2010, nests were collected at Eragny $(n=10)$, Aubergenville $(n=20)$, Nanterre $(n=10)$, SaintMaur-des-Fossés $(n=5)$, and also in the main range, at Amilly $(n=10)$, Brétigny $(n=11)$, Dourdan $(n=13)$, Chartres $(n=10)$, Pithiviers $(n=10)$, Tours $(n=10)$. The nests were then dissected in the laboratory and the number of living larvae and dead larvae were counted to calculate the survival rate.
The effect of these cold periods on survival rate was investigated using hourly temperatures provided by the French meteorological center, Météo-France (from January 1st to 11th, 2009 and from January 1st to 13th, 2010). For each sampling site, the nearest weather station with available information was selected to determine the absolute minimum temperature and the coldness severity (number of consecutive hours below $0{ }^{\circ} \mathrm{C}$ and $-10^{\circ} \mathrm{C}$ ). Although, the survival rate was not estimated at Obernai, temperature data during these cold waves were included in the study.

\section{Results}

Dispersal mechanism

\section{Dispersal capabilities}

A total of 47 females were tested on the flight mill, but only 37 were capable of flying more than $50 \mathrm{~m}$. Among these $11(30 \%)$ flew farther than the $2 \mathrm{~km}$ maximum reported and $6(16 \%)$ flew farther than $5 \mathrm{~km}$ (Fig. 2). The average flying distance was $1.7 \mathrm{~km}$ and the maximum distance recorded was $10.5 \mathrm{~km}$.

The distance between pioneer colonies near Paris and the main range was $30-55 \mathrm{~km}$, and even further $(189 \mathrm{~km})$ for Obernai (Table 2). The minimum distance from a pioneer colony near Paris to a previously established colony was $14 \mathrm{~km}$. For Obernai, the minimum distance to a pioneer colony already established near Paris was $347 \mathrm{~km}$.

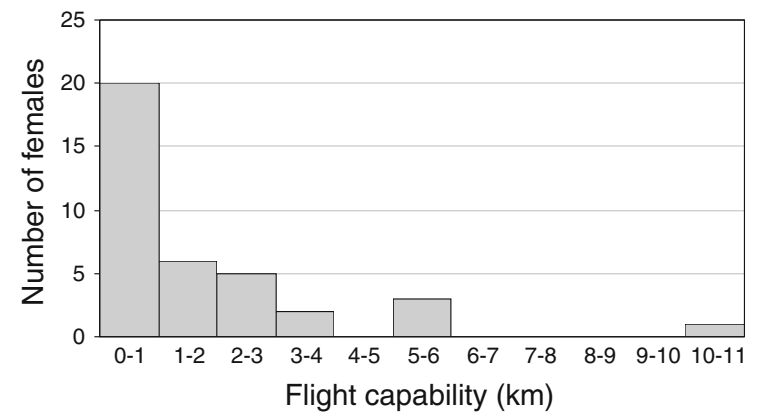

Fig. 2 Frequency distribution of the flight capabilities of females of PPM on a flight mill (24 h cumulated flight) 
Genetic analyses

COI data All the sequenced individuals from SaintMaur-des-Fossés, Nanterre and Bailly-Romainvilliers exhibited a mitotype from mitogroup $A_{2}$, which is found from south-eastern Spain to north-western France, more or less along the Greenwich meridian (see Rousselet et al. 2010). All the individuals from Eragny and Aubergenville exhibited a mitotype from mitogroup $A_{1}$, which is found from Italy to Eastern France, including the Alps, the Massif Central and the Rhône and Saône valleys.

Microsatellite data The multilocus assignment scores of each individual to the seven reference populations are given in Appendix S3 for the five pioneer colonies discovered beyond the north-western edge of PPM natural expansion near Paris. All the first rank scores were higher than 0.50 , three-quarters were higher than 0.70 and more than one-third were higher than 0.90. For most individuals, they were much higher than those at the other ranks (see appendix S3), we therefore focussed on the total number of individuals assigned as first rank to each reference population (Fig. 3). In Saint-Maur-des-Fossés and Nanterre, most of the genotyped individuals were assigned to north-western France as first rank. In Eragny and Aubergenville, most of the individuals were assigned to Italy and south-eastern France, and to Italy and north-eastern France respectively. In BaillyRomainvilliers, most of the individuals were assigned to the Iberian Peninsula and south- western France.

\section{Natural enemies}

The 84 egg-masses studied contained 19,731 eggs. Each egg-mass was wrapped around two needles of
Pinus nigra. Egg parasitoids were only found in colonies located in the main range. All the 34 eggmasses analysed from the pioneer colonies did not show any parasitoids (Table 3 ). In the main range, $44 \%$ of the collected egg-masses contained egg parasitoids at Poitiers and $36 \%$ at Tours, but the mean rate of parasitization of individual eggs was relatively low (around 3\%). The hatching rate in the main range was slightly but not significantly lower than in pioneer colonies $(94.6 \%$ vs. more than $97.5 \%$; Mann-Whitney test $W=589, P=0.07$ ) (Table 3 ). After the analysis of meconium left in parasitized eggs, three species of egg parasitoids were identified. These were Baryscapus servadeii (Domenichini, 1965) (Hymenoptera: Eulophidae), Ooencyrtus pityocampae (Mercet, 1921) (Hymenoptera: Encyrtidae) and Trichogramma $s p$ (Hymenoptera: Trichogrammatidae).

The tachinid larval parasitoid, Phryxe caudata, was found in nests at all sampled sites. In the main range, $10-20 \%$ of the nests were parasitized by at least one tachinid fly compared to $15-30 \%$ in pioneer colonies.

\section{Establishment capability}

Following the cold periods, the population survival rate was generally higher in the pioneer colonies than in the main range (this result was significant in 2010: $82 \%$ compared to $54 \%$ on average, Mann-Whitney test $W=1977, P<0.01$, but not in 2009: $78 \%$ compared to $73 \%, W=376, P=0.07$ ) (Tables 4,5 ).

The absolute minimum temperature was higher in the pioneer colonies than in the main range (significant result in $2010:-7.7^{\circ} \mathrm{C}$ compared to $-15.2^{\circ} \mathrm{C}$ on average, Mann-Whitney test $W=16, P=0.01$, but not in 2009 : $-10.8^{\circ} \mathrm{C}$ compared to $-13.0^{\circ} \mathrm{C}, W=12$, $P=0.11$ ). The number of consecutive hours below $0^{\circ} \mathrm{C}$ was not significantly different between pioneer
Table 2 Distance matrix $(\mathrm{km})$ between pioneer colonies at first year of detection and the potential source of dispersers (pioneer colonies previously established and main range in 2005-2006)

Years in brackets indicate the first PPM detection

\begin{tabular}{lclr}
\hline $\begin{array}{l}\text { Pioneer colony at first } \\
\text { year of detection }\end{array}$ & \multicolumn{2}{l}{ Potential source of dispersers } \\
\cline { 2 - 4 } & $\begin{array}{l}\text { Main range } \\
\text { boundary }\end{array}$ & $\begin{array}{l}\text { Bailly-Romainvilliers } \\
(2003)\end{array}$ & $\begin{array}{l}\text { Nanterre } \\
(2007)\end{array}$ \\
\hline Bailly-Romainvilliers (2003) & 39.37 & & \\
Nanterre (2007) & 42.44 & 43.36 & 27.97 \\
Aubergenville (2008) & 50.54 & 71.38 & 14.46 \\
Eragny (2008) & 55.01 & 54.90 & 391.83 \\
Obernai (2008) & 189.36 & 347.55 & 23.96 \\
Saint-Maur-des-Fossés (2008) & 29.63 & 22.97 & \\
\hline
\end{tabular}




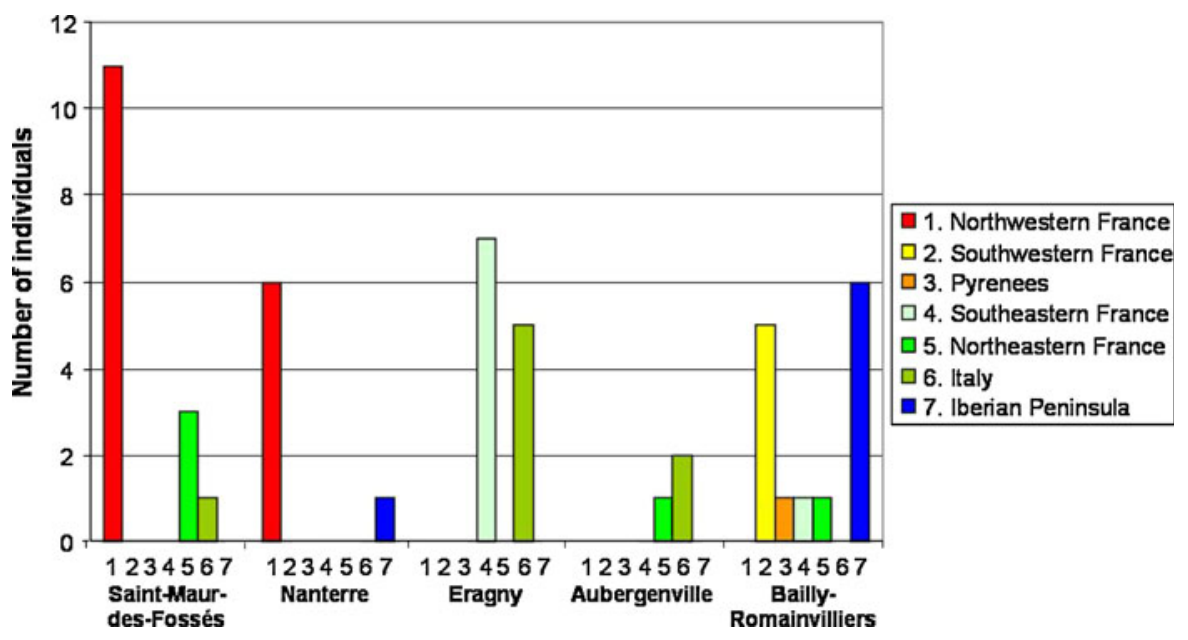

Fig. 3 Results of microsatellite assignment tests for the 51 individuals from the five pioneer colonies located near Paris to the seven western European regions. For each individual, only the reference population with the best assignment score is retained (first rank result), and, for each colony, the bars represent the total number of individuals assigned as first rank to each reference population (see Appendix S3 for reference population scores from the second to the seventh rank for each individual)
Table 3 Parasitism of eggs and larval nests in the main range and in pioneer colonies

All samplings were carried out on Pinus nigra

\begin{tabular}{|c|c|c|c|c|}
\hline \multirow[t]{2}{*}{ Sampling sites } & \multicolumn{2}{|c|}{ Main range } & \multicolumn{2}{|c|}{ Pioneer colonies } \\
\hline & Poitiers & Tours & Eragny & Aubergenville \\
\hline Number of egg-massses & 25 & 25 & 16 & 18 \\
\hline Mean eggs per egg-mass & 236 & 249 & 262 & 233 \\
\hline Rate of hatched larvae (\%) & 94.61 & 94.57 & 99.10 & 97.52 \\
\hline Rate of parasitized eggs (\%) & 2.84 & 3.33 & 0 & 0 \\
\hline Rate of parasitized egg-masses (\%) & 44 & 36 & 0 & 0 \\
\hline Number of nests & 10 & 10 & 10 & 20 \\
\hline Rate of parasitized nests $(\%)$ & 20 & 10 & 30 & 15 \\
\hline
\end{tabular}

and colony establishment was assisted by urban heated environments.

Coming farther than the edge of the main range

The estimated dispersal capacity of the female adults (10.5 km at most) was lower than the distance an individual would have to fly from the main range to reach these isolated locations $(30-55 \mathrm{~km}$ and $189 \mathrm{~km}$ to the main range; Table 2). Therefore, it is unlikely that natural dispersal from the main range gave rise to a pioneer colony. Because the distance between pioneer colonies near Paris ranged from 14 to $71 \mathrm{~km}$, possible natural dispersal cannot be excluded between certain pioneer colonies (i.e. Eragny and Nanterre). This was however unlikely because this between-colony distance exceeded the estimated flight capacity by $38 \%$ 
Table 4 Temperature during the cold period in 2009 (Jan 1-11) and survival rates

\begin{tabular}{clrrrr}
\hline & Location & Tmin & H0 & H10 & S \\
\hline Pioneer & Aubergenville & -13.7 & 55 & 9 & 75.9 \\
colonies & Eragny & -11.2 & 46 & 2 & 75.8 \\
& Nanterre & -8.7 & 49 & 0 & 81.7 \\
& Saint-Maur-des- & -11.2 & 56 & 5 & 79.1 \\
& Fossés & & & & \\
Main range & Cbernai & -12.2 & 226 & 12 & $*$ \\
& Chartres & -11.9 & 106 & 13 & 75.1 \\
& Baccon & -12.5 & 107 & 12 & 70.5 \\
& Melun & -13.8 & 189 & 16 & 74.0 \\
\hline
\end{tabular}

Tmin represents the absolute minimum temperature $\left({ }^{\circ} \mathrm{C}\right), \mathrm{H} 0$ the number of consecutive hours below $0^{\circ} \mathrm{C}, \mathrm{H} 10$ the number of hours below $-10^{\circ} \mathrm{C}$ and $\mathrm{S}$ the survival rate (\%)

*not measured

Table 5 Temperature during the cold period in 2010 (Jan 1-13) and survival rates

\begin{tabular}{llrrrr}
\hline & Location & Tmin & H0 & H10 & S \\
\hline Pioneer & Aubergenville & -5.7 & 46 & 0 & 75.6 \\
colonies & Eragny & -5.7 & 46 & 0 & 92.3 \\
& Nanterre & -5.7 & 117 & 0 & 82.5 \\
& Saint-Maur-des- & -8.7 & 164 & 0 & 85.3 \\
& Fossés & & & & \\
Main range & Obernai & -10.7 & 242 & 1 & $*$ \\
& Chartres & -14.9 & 228 & 12 & 56.9 \\
& Dourdan & -19.9 & 184 & 15 & 59.6 \\
& Brétigny & -19.9 & 184 & 15 & 32.6 \\
& Pithiviers & -14.5 & 182 & 14 & 40.8 \\
& Amilly & -11.7 & 185 & 6 & 72.0 \\
\hline
\end{tabular}

Tmin represents the absolute minimum temperature $\left({ }^{\circ} \mathrm{C}\right), \mathrm{H} 0$ the number of consecutive hours below $0^{\circ} \mathrm{C}, \mathrm{H} 10$ the number of hours below $-10^{\circ} \mathrm{C}$ and $\mathrm{S}$ the survival rate (\%)

*not measured

and each populations was assigned to a different source population (Fig. 3). While caution is needed when extrapolating lab-based estimates of flight capabilities to the dispersal capabilities in natural conditions (due to different behaviours of individuals and capability to measure the spread in the field), these new estimates are more consistent with the natural spread rate observed in the south of the Paris Basin (5.6 km per year; Battisti et al. 2005) than the maximum flight capabilities previously reported in literature (around 2 km; Démolin 1969).
Three of the five pioneer colonies probably originated from populations at least $260 \mathrm{~km}$ distant (see Appendix S3 and S4). In Eragny, Aubergenville and Bailly-Romainvilliers, no individual was genetically assigned as first rank to the nearest north-western populations of France (Fig. 1, 3). Eragny and Aubergenville colony mitochondrial and nuclear markers were congruent and indicated a much more eastern origin, possibly from south-eastern France or Italy according to the present dataset. For Bailly-Romainvilliers, the detected mitotype is found from Eastern Spain to north-western France (i.e. both in distant and close populations to the colonies), but the microsatellite markers clearly indicated an origin from south-western France or the Iberian Peninsula. The precise origin of all these three colonies still remains unclear probably because of large unsampled areas and the too low number of microsatellites which were used. Despite this the assignment scores to the north-western group are very weak for all the studied individuals (appendix S3).

Only two of the pioneer colonies probably originated from north-western France according to the assignment tests (not contradicted by mitochondrial data). However, the present data did not indicate whether they originated from the northernmost and nearest populations along the edge of the main range or from the southernmost or westernmost populations of the Paris Basin, a further tens of kilometres distant. Some colonies, especially at Saint-Maur-des-Fossés, could have been reached by males, whose flight distances are greater than those of females (Démolin 1969). It might be difficult therefore to track with confidence the precise origin of the colonies observed in north-western France several generations after a human-mediated translocation. Moreover, weak genetic differentiation or strong allele frequency distortion after bottleneck events can also blur things.

Potential pathway for long-distance jumps

If specific parasitoids found in pioneer colonies have been co-introduced with their host, the presence/ absence of different parasitoid species associated with different developmental stages can help determine the stage of introduction and identify the potential pathway of spread. Since only the tachinid Phryxe caudata, a specific larval-pupal parasitoid, was detected in the pioneer colonies, this suggests that PPM was introduced at the larval or pupal stage. Indeed, the first 
tachinid generation develops inside the 2 nd to the 4th instar of its host, and the second generation parasitizes the last instar larvae to emerge from the pupae developing in the soil (Biliotti 1956; Géri 1980; Buxton 1990). Recently planted pine trees might shelter larvae, however PPM rarely attacks trees less than 4-5 years old. Also larvae living gregariously in silk nests are easy to detect and generally removed by managers because they are pests. Consequently, this pathway of introduction is unlikely and Phryxe caudata was probably introduced along with PPM pupae. An accidental transportation of egg-masses can be excluded because pine trees are not usually planted during the egg stage (in summer). This is consistent with the absence of egg parasitoids in pioneer colonies contrary to the main range. An accidental transportation of adults is possible too, but the short life-span of adult females (usually around 24 h; Démolin 1969) and the presence of parasitoids associated with larval stage, would suggest otherwise. It is most likely, therefore, that the pupal stage was accidentally introduced. Pupae are not easily detectable in the soil and may have been introduced with transplanted large trees moved with a large amount of soil. PPM can enter an extended diapause at the pupal stage, staying several years in the soil, which also increases the probability of accidental movement of the insect at this stage (Géri 1980).

Pupal movement was probably responsible for the introduction of the related oak processionary moth, Thaumetopoea processionea (Linnaeus) (Lepidoptera: Notodontidae), from Continental Europe into the United Kingdom (Evans 2008). Evans (2010) argued that the likelihood of pests being present increases dramatically if soil remains associated with the host plant, particularly for potted plants and, especially, for large rootballed specimens. Root balling is considered as 'an ecosystem in a pot', with most of the associated organisms being also transported hidden and of unknown identity.

Better climatic conditions in urban areas

Following the cold periods recorded during the winters between 1986 and 1988 and in 1994, PPM populations crashed suddenly in the main range (Bouhot-Delduc 2005a), and PPM distribution retracted from northern and mountainous locations (Bouhot-Delduc 2005b). In contrast, the pioneer colonies located near Paris far beyond the main range better survived the cold winters in 2009 and 2010 than those of the main range. Pioneer colony winter larval survival ranged from 76 to $92 \%$ in these years. Colony localities near Paris and to some extent at Obernai, are in urban areas of dense human population which behave like heat islands that may have enhanced the establishment success of the new colonies. Although PPM is mainly a forest insect, isolated urban trees in private gardens, in parks, along roads, or on roundabouts are exposed to the sun and highly suitable for the insect. This forest pest has therefore become an urban nuisance.

The mean temperature increase over the last few decades has made the climate more favourable for PPM establishment outside the main range in France and Italy (Battisti et al. 2005; Robinet et al. 2007), and probably in many other European countries. The Paris Basin was known to be favourable for the winter survival of the species (Robinet et al. 2007). Consequently, an accidental transportation of some individuals near Paris via human activities could have been an introduction and establishment pathway for some time. Why these pioneer colonies were only discovered in the 2000s remains unclear.

\section{Greater dispersal capabilities}

The rate of natural invasion of PPM into new areas mediated by warming climates (suggested by Kerr 2009) and urban heat islands depends on its dispersal capability. This study provides strong evidence, however, that human-mediated dispersal can create satellite populations and accelerate PPM spread. In the future, it will be important to quantify this chance of accidental transportation to predict these long-distance jumps and the expansion of the species' distribution. Furthermore, these jumps may also occur within the main range of PPM because the diffusion coefficient (rate of spread) was relatively high in the Paris Basin between 2007 and 2009 (Roques et al. 2011).

More generally, this example for PPM, where there has been a natural range shift from combined human transfer to climatically-favourable new habitats leading to continuously enlarging populations, shows that distinguishing between native and alien species may become increasingly difficult with continued climate change (Walther et al. 2009). This study also demonstrates the interest of using genetic markers and individual-based assignment tests to 
separate long-distance human-assisted spread from the natural dispersal capacity of the species and for the development of more effective pest surveillance. This approach is of particular interest for species such as PPM, which via their urticating hairs can affect human health near such pioneer colonies.

Acknowledgments We greatly acknowledge support for this work from the FP7 EU project PRATIQUE KBBE-2007-212459 (Enhancements of pest risk analysis techniques; Baker et al. 2009; https://secure.fera.defra.gov.uk/pratique/index.cfm), the FP7 EU project BACCARA KBBE-2008 (Biodiversity and climate change, a risk Analysis; http://www.baccara-project.eu/ ), the URTICLIM project "Anticipation des effets du changement climatique sur l'impact écologique et sanitaire d'insectes forestiers urticants" of the French "Agence Nationale de la Recherche' (ANR 07BDIV 013), the FAST project (Analyse des évolutions régionalisées de la forêt métropolitaine face aux aléas climatiques et biotiques, avec des scénarios de gestion forestière d'atténuation et d'adaptation) of the French Ministry of Ecology and Sustainable Development, and the DGFAR project of the French Ministry of Agriculture (N॰59-02 E13/05). We thank Météo-France for providing hourly temperatures during the cold waves. The authors are indebted to Jean-Claude Martin, René Mazet, Pierre Ménassieu, Hervé Jactel, Patrick Pineau, Jean Poirot, Andrea Battisti, Helena Santos, Manuela Branco, Ramón González Ruiz, Maria J. Lombardero for their help in collecting samples. We are also very grateful to Emmanuelle Magnoux, Claudine Courtin, Géraldine Gouppil, Sophie Delamaire, Yeliz Yildiz, Nese Kaplan, Magalie Devavry, Antoine Daunay, Ruixing Zhao, Stéphanie François, Romain Leroux, Laure Maudemain, Elisa Prat for lab technical assistance, to Olivier Denux for creating the GIS map, to Patrick Pineau and Jean-Paul Raimbault for counting the larvae collected during the cold waves, to Jean Poirot, Céline Magen, Patrick Scepi, and $\mathrm{Mr}$ Lalliaume for reporting the presence of a colony at Obernai, Aubergenville, Saint-Maur-Des-Fossés, and Eragny, respectively. A special thanks to Hubert Pauly and François-Xavier Saintonge (DSF) for the insect surveillance and precious help. We gratefully acknowledge Carole Kerdelhué and Marie-Anne Auger-Rozenberg for useful comments, and the guest editor and the anonymous reviewers for their suggested corrections.

Open Access This article is distributed under the terms of the Creative Commons Attribution Noncommercial License which permits any noncommercial use, distribution, and reproduction in any medium, provided the original author(s) and source are credited.

\section{References}

Andrewartha HG, Birch LC (1984) The ecological web: more on the distribution and abundance of animals. University of Chicago Press, Chicago

Baker RHA, Battisti A, Bremmer J et al (2009) PRATIQUE: a research project to enhance pest risk analysis techniques in the European Union. EPPO Bull 39:93-97
Battisti A, Stastny M, Netherer S, Robinet C, Schopf A, Roques A, Larsson S (2005) Expansion of geographic range in the pine processionary moth caused by increased winter temperatures. Ecol Appl 15:2084-2096

Battisti A, Holm G, Gafrell B, Larsson S (2011) Urticating hairs in arthropods: their nature and medical significance. Annu Rev Entomol 56:203-220

Beck SD (1983) Insect thermoperiodism. Annu Rev Entomol 28:91-108

Biliotti E (1956) Biologie de Phryxe caudata Rondani (Dipt. Larvaevoridae) parasite de la processionnaire du pin (Thaumetopoea pityocampa Schiff). Rev Path Veg Entomol Agric France 35:50-65

Biliotti E (1958) Les parasites et prédateurs de Thaumetopoea pityocampa Schiff. (Lepidoptera). Entomophaga 3:23-34

Bouhot-Delduc L (2005a) La gradation de la chenille processionnaire du pin a culminé sur la façade atlantique lors de l'hiver 2003-2004. La santé des forêts (France) en 2004. French Ministry of Agriculture and Fisheries, Paris

Bouhot-Delduc L (2005b) Dynamique des populations de la processionnaire du pin et extension de son aire de colonisation de 1981 à 2004 en France. La santé des forêts (France) en 2004. French Ministry of Agriculture and Fisheries, Paris

Buffo E, Battisti A, Stastny M, Larsson S (2007) Temperature as a predictor of survival of the pine processionary moth in the Italian Alps. Agric For Entomol 9:65-72

Buxton RD (1990) The influence of host tree species on timing of pupation of Thaumetopoea pityocampa Schiff. (Lep., Thaumetopoeidae) and its exposure to parasitism by Phryxe caudata Rond. (Dipt., Larvaevoridae). J Appl Ent 109:302-310

Démolin G (1969) Comportement des adultes de Thaumetopoea pityocampa Schiff. Dispersion spatiale, importance écologique. Ann For Sc 26:81-102

Devkota B, Breuer M, Schmidt GH (1992) Observations on the flight activity of the pine processionary moth Thaumetopoea pityocampa (Den. and Schiff.) in Greece using synthetic sex-pheromone and light traps (Insecta: Lepidoptera: Thaumetopoeidae). Boll Zool Agr Bachic 24:147-157

Evans H (2008) Increasing global trade and climate change: co-factors increasing the international movement and establishment of forest pests. In: Alien invasive species and international trade, 2nd meeting of IUFRO working unit 7.03.12, 26-30 May 2008. National conservation training center, Shepherdstown, WV, USA. Available at http://www.forestry.gov.uk/pdf/IUFRO_Shepherdstown_ Evans_Trade_and_Climate_Change.pdf/\$FILE/IUFRO_ Shepherdstown_Evans_Trade_and_Climate_Change.pdf

Evans H (2010) Pest risk analysis-organisms or pathways? NZ J For Sc 40(suppl):35-44

Géri C (1980) Application des méthodes d'études démécologiques aux insectes défoliateurs forestiers. Cas de Diprion pini L. (Hyménoptère: Diprionidae). Dynamique des populations de la processionnaire du pin Thaumetopoea pityocampa Schiff. (Lépidoptère: Thaumetopoeidae) dans l'île de Corse. PhD thesis, University of Paris-Sud Orsay

Gilbert M, Gregoire J-C, Freise JF, Heitland W (2004) Longdistance dispersal and human population density allow the prediction of invasive patterns in the horse chestnut leafminer Cameraria ohridella. J Anim Ecol 73:459-468 
Hall TA (1999) BioEdit: a user-friendly biological sequence alignment editor and analysis program for Windows 95/98/NT. Nucleic Acids Symp Ser 41:95-98

Huchon H, Démolin G (1970) La bioécologie de la processionnaire du pin. Dispersion potentielle-dispersion actuelle. Rev For Fr 22:220-233 (special issue "La lutte biologique en forêt")

Kerdelhué C, Magnoux E, Lieutier F, Roques A, Rousselet J (2006) Comparative population genetic study of two oligophagous insects associated with the same hosts. Heredity 97:38-45

Kerdelhué C, Zane L, Simonato M, Salvato P, Rousselet J, Roques A, Battisti A (2009) Quaternary history and contemporary patterns in a currently expanding species. BMC Evol Biol 9:220

Kerr RA (2009) What happened to global warming? Scientists say just wait a bit. Science 326:28-29

Klein Tank AMG, Wijngaard JB, Können GP et al (2002) Daily dataset of 20th-century surface air temperature and precipitation series for the European Climate Assessment. Int J Climatol 22:1441-1453. Data and metadata available at http://eca.knmi.nl

Koch FH, Yemshanov D, McKenney DW, Smith WD (2009) Evaluating critical uncertainty thresholds in a spatial model of forest pest invasion risk. Risk Anal 29:1227-1241

Leblond A, Martin J-C, Napoléone C, Geniaux G, Robinet C, Provendier D, Gutleben C (2010) La processionnaire du pin vue par ses gestionnaires. Une enquête auprès des communes françaises donne un nouveau regard sur ce ravageur. Phytoma 633:18-23

Liebhold AM, Tobin PC (2008) Population ecology of insect invasions and their management. Annu Rev Entomol 53:387-408

Muirhead JR, Leung B, van Overdijk C et al (2006) Modelling local and long-distance dispersal of invasive emerald ash borer Agrilus planipennis (Coleoptera) in North America. Divers Distrib 12:71-79

Netherer S, Schopf A (2010) Potential effects of climate change on insect herbivores in European forests-General aspects and the pine processionary moth as specific example. For Ecol Manage 259:831-838

Neubert MG, Caswell H (2000) Demography and dispersal: calculation and sensitivity analysis of invasion speed for structured populations. Ecology 81:1613-1638

Paetkau D, Slade R, Burden M, Estoup A (2004) Genetic assignment methods for the direct, real-time estimation of migration rate: a simulation-based exploration of accuracy and power. Mol Ecol 13:55-65

Parmesan C (2006) Ecological and evolutionary responses to recent climate change. Annu Rev Ecol Evol Syst 37:37-69

Parmesan C, Yohe G (2003) A globally coherent fingerprint of climate change impacts across natural systems. Nature 421:37-42

Parmesan C, Ryrholm N, Stefanescu C et al (1999) Poleward shifts in geographical ranges of butterfly species associated with regional warming. Nature 399:579-583

Pimentel C, Ferreira C, Nilsson J-A (2010) Latitudinal gradients and the shaping of life-history traits in a gregarious caterpillar. Biol J Linn Soc 100:224-236
Piry S, Alapetite A, Cornuet J-M, Paetkau D, Baudouin L, Estoup A (2004) GeneClass2: a software for genetic assignment and first-generation migrant detection. J Hered 95:536-539

Rannala B, Mountain JL (1997) Detecting immigration by using multilocus genotypes. Proc Natl Acad Sci USA 4:9197-9201

Robinet C, Roques A (2010) Direct impacts of recent climate warming on insect populations. Integr Zool 5:132-142

Robinet C, Baier P, Pennerstorfer J, Schopf A, Roques A (2007) Modelling the effects of climate change on the potential feeding activity of Thaumetopoea pityocampa (Den. \& Schiff.) (Lep., Notodontidae) in France. Glob Ecol Biogeogr 16:460-471

Robinet C, Roques A, Pan HY, Fang GF, Ye JR, Zhang YZ, Sun JH (2009) Role of human- mediated dispersal in the spread of the pinewood nematode in China. PLoS One 4(2):e4646. doi:10.1371/journal.pone.0004646

Robinet C, Rousselet J, Goussard F, Roques A (2010) Modelling the range expansion of an urticating moth with global warming: a case study from France. In: Settele J (ed) Atlas of biodiversity risks-from Europe to the globe, from stories to maps. Pensoft, Sofia, pp 82-83

Roques L, Soubeyrand S, Rousselet J (2011) A statisticalreaction-diffusion approach for analyzing expansion processes. J Theor Biol 274:43-51

Rousselet J, Magnoux E, Kerdelhué C (2004) Characterization of five microsatellite loci in the pine processionary moth Thaumetopoea pityocampa (Lepidoptera Notodontidae Thaumetopoeinae). Mol Ecol Notes 4:213-214

Rousselet J, Zhao R, Argal D, Simonato M, Battisti A, Roques A, Kerdelhué C (2010) The role of topography in structuring the demographic history of the pine processionary moth, Thaumetopoea pityocampa (Lepidoptera: Notodontidae). J Biogeogr. doi:10.1111/j.1365-2699.2010.02 289.x

Salvato P, Battisti A, Concato S, Masutti L, Patarnello T, Zane L (2002) Genetic differentiation in the winter pine processionary moth (Thaumetopoea pityocampa-wilkinsoni complex), inferred by AFLP and mitochondrial DNA markers. Mol Ecol 11:2435-2444

Salvato P, Simonato M, Zane L, Patarnello T, Masutti L, Battisti A (2005) Do sexual pheromone traps provide biased information of the local gene pool in the pine processionary moth? Agric For Entomol 7:127-132

Santos H, Rousselet J, Magnoux E, Paiva MR, Branco M, Kerdelhué C (2007) Genetic isolation through time: allochronic differentiation of a phenologically atypical population of the pine processionary moth. Proc R Soc London Ser B 274:935-941

Sharov AA, Liebhold AM (1998) Model of slowing the spread of gypsy moth (Lepidoptera: Lymantriidae) with a barrier zone. Ecol Appl 8:1170-1179

Shigesada N, Kawasaki K (1997) Biological Invasions: theory and practice. Oxford University Press, New York

Tanzen E, Schmidt GH (1995) Identification by meconia of four species of egg parasitoids of Thaumetopoea pityocampa (Den. \& Schiff.) (Insecta, Lepidoptera, Notodontidae). Boll Zool Agric Bachic Ser II 27:61-70

Trenberth KE, Jones PD, Ambenje P et al (2007) Observations: surface and atmospheric climate change. In: Solomon $\mathrm{S}$ 
et al (eds) Climate change 2007: the physical science basis. Contribution of working group I to the fourth assessment report of the inter governmental panel on climate change. Cambridge University Press, Cambridge, pp 235-336
Walther GR, Post E, Convey P et al (2002) Ecological responses to recent climate change. Nature 416:389-395 Walther GR, Roques A, Hulme PE et al (2009) Alien species in a warmer world: risks and opportunities. Trends Ecol Evol 24:686-693 